\title{
AN APPRAISAL OF ENVIRONMENTAL INTERPRETIVE POLICIES AND STRATEGIES OF NIGERIA NATIONAL PARKS
}

\author{
AA Ogunjinmi $^{1} *$, LO Ojo $^{2}$, SA Onadeko $^{3}$ and O Oguntoke ${ }^{2}$ \\ ${ }^{1}$ Department of Wildlife and Environmental Resources Management, College of Agriculture, Osun State Uni- \\ versity, P.M.B. 4014, Ejigbo, Osun State, Nigeria \\ ${ }^{2}$ Department of Environmental Management and Toxicology, University of Agriculture, P.M.B. 2240, \\ Abeokuta, Ogun State, Nigeria \\ ${ }^{3}$ Department of Forestry and Wildlife Management, University of Agriculture, P.M.B. 2240, Abeokuta, Ogun \\ State, Nigeria
}

Accepted: $15^{\text {th }}$ May 2009

\begin{abstract}
This research was carried out to appraise the environmental interpretive policies and strategies of Nigeria National Parks. Four National Parks-Chad Basin National Parks (CBNP), Kainji Lake National Park (KLNP), Okomu National Park (OKNP) and Yankari National Park (YNP, now Yankari Game Reserve) representing the major ecological zones of Nigeria were selected for the study. Data were collected from the management of the Parks through interview guide adapted from the Department of Natural Resources and Environment and Parks, Victoria, Australia; these were analysed by using descriptive statistics. The study revealed that the business structure for these parks is public service model and that they have legislated responsibility for providing information and education and considered interpretation to be of central importance to their operations; although they have varying levels of importance attached to various interpretation/interpretive functions. Interpretive policies and strategies adopted by the parks include management policy, education policy and strategy, management plans, action plans, guidelines and manuals. Key audiences considered for interpretive services were visitors from schools, first-time visitors, park neighbours, tertiary institutions, overseas visitors and special interest groups. The study concluded that greater emphasis is needed in developing appropriate interpretive plans and programs that can shape visitors'/ and park neighbours attitude towards National Parks' policies and activities as well as using interpretive services to project the tourism potentials of Nigeria to the outside world in order to optimize the gains from global tourism market and to enhance the achievement of Millennium Development Goals (MDGs) of eradicating extreme poverty (through increased economic benefits of local communities from ecotourism ) and ensuring environmental sustainability in the country.
\end{abstract}

Key words: Environmental Interpretive Services, Interpretation, National Parks, Nigeria, Policies

\section{INTRODUCTION}

All over the world, particularly in developing and third world countries, human dimension aspect of natural resources management has become a serious cause of concern. According to Whitmore and Sayer (1992), human impact on the global environment has increased greatly in recent centuries, and especially during the last 50 years. Westing et al. (2001), posited that humans ever than before are utilizing all of the world's major renewable natural resources at the rate exceeding their natural abilities to renew themselves while introducing pollutants into the environment at levels increasingly beyond the point at which they can dissipate or decompose into insignificance. The report added that humans more than ever before are encroaching drastically upon what remains or relatively wild nature throughout the world. Forests have been exploited and cleared, while croplands have increased in extent and uses have intensified. Domestic livestock have increased in numbers, and their grazing pressures have increased in severity. As human activities exert pressures on the global environment, biological diversity declines as habitats are transformed and the populations of some species dwindle to the point of extinction in some cases (Whitmore and Sayer 1992). More and more wild animals and plants species, all over the world are being identified as threatened or endangered (Onadeko and Meduna 1984). Biodiversity is now vanishing at an unprecedented rate (Wilson, 1988; Reid and Miller 1989). Saving our beleaguered environment is the most pressing problem facing man (Nisbet 1991 cited in Peters 1995).

Consequent upon the spate of unsustainable utilization and wanton destruction of biodiversity, protected areas are being established under the guidance of International Union of Conservation of Nature (IUCN) to conserve biodiversity in many countries of the world. The establishment of protected areas has become a global business in recent 
decades (Abramovitz 1991) and the types of protected areas have become much more sophisticated. National Parks remain the most common type of protected area, especially in developing countries. Ensuring public support for the natural resource management program of the National Park Service is critical to the long-term preservation of parks. Without the good-will and support of host communities resource managers are sure to face difficulties and misunderstanding in their efforts to resolve the many issues facing parks today. To gain support, the National Park Service is engaged in various activities that encourage visitors and park neighbours to learn about the role of park management and eco-development. They share the common approach of interpreting scientific information in non-technical and engaging ways that stimulate consideration of the many challenges inherent in natural resource management (NPS 1998). One of these activities is interpretation. Interpretation according to Tilden (1977) is an educational activity, which aims to reveal meaning and relationships through the use of original objects by first-hand experience and by illustrative media rather than communicate factual information. The concept of interpretation is illustrated by the saying, "through interpretation understanding, through understanding appreciation, through appreciation protection (Tilden 1977). The benefits of resource interpretation are many: a better informed public and therefore empowered constituency of park supporters, a closer bond between parks and neighbours, and a public vested in the rational application of science in the care of park natural resources. It has a direct and indirect contribution to sustainable development (Wolfgang 2002). First, through promotion of sustainable resource use, resource management and social development in the host region (on-site contribution), and the other through contributing to environmental awareness and changes of behaviour in visitors (off-site contribution).

Prior to 1979 and with the emergence of the Kainji Lake National Park as the first national park in Nigeria, national parks as a concept in biodiversity management was alien, though the first game reserve-Yankari Game Reserve was long established since 1935. This revolution has therefore largely been affected by poorly informed publics (local communities, visitors, politicians, policy makers and other stakeholders). This low level of information is not only about the existing resources in the national parks but also impending tragedies likely to be inflicted on the human component of the ecosystem if the spate of unsustainable utilization of the resources continues. Engendering public support for conservation goals and activities of Nigeria National Parks is of critical issue. The present study was carried out to examine the institutional commitments to interpretive services as a public relations and communications' activities as well as their management in Nigeria National Parks with the view of determining whether they conform to what obtains in other countries where the concept of national parks have long been established.

\section{METHODOLOGY}

The study was carried out in Kainji Lake National Park (KLNP), Yankari National Park (YNP, now Yankari Game Reserve), Chad Basin National Park (CBNP) and Okomu National Park (OKNP). These were selected to represent the major ecological zones where National Parks are located: Okomu National Park (Rainforest), Chad Basin National Park (Sudan/Sahel savanna), Yankari National Park (Sudan savanna) and Kainji Lake National Park (Northern Guinea savanna) (Table 1 and Fig. 1). Data were obtained by the use of interview guide adapted from Department of Natural Resources and Environment (1999). The interview guide comprises business structure of the National Parks, requirements, commitment, policies and planning for interpretive services. Ranking of interpretation functions was through preference ranking with the most important being first $\left(1^{\text {st }}\right)$ and the least important being sixth $\left(6^{\text {th }}\right)$. Data obtained were analysed using descriptive statistics.

\section{RESULTS}

The study revealed that the business structure for all the parks studied is public service model (i.e. a government agency is responsible both for policy/ strategy direction and service delivery (Table 2). The study further showed that the selected National Parks have legislated responsibility for providing information/education; and they also considered interpretation to be of central importance to their operations i.e. one of their four or five main functions. However, there is no reference to interpretation in their mission/vision statements. They clearly identified the functions of interpretation considered to be of central importance as increasing visitors' enjoyment, increasing visitors' awareness and understanding, increasing community support, chang-

Table 1: Location, Land Area and the Ecotypes of the selected National Parks

\begin{tabular}{|c|c|c|c|c|}
\hline Name & $\begin{array}{l}\text { Location } \\
\text { (State) }\end{array}$ & $\begin{array}{l}\text { Land } \\
\text { area } \\
\left(\mathrm{km}^{2}\right)\end{array}$ & $\begin{array}{l}\text { Latitude/ } \\
\text { Longitude }\end{array}$ & Ecological zone \\
\hline$\overline{\mathrm{CBNP}}$ & $\begin{array}{l}\text { Borno and } \\
\text { Yobe }\end{array}$ & 2245 & $\begin{array}{l}12^{0} 25^{1} \mathrm{~N} / 14^{0} \\
15^{1} \mathrm{E}\end{array}$ & $\begin{array}{l}\text { Sudan/Sahel Sa- } \\
\text { vanna }\end{array}$ \\
\hline KLNP & $\begin{array}{l}\text { Niger and } \\
\text { Kwara }\end{array}$ & 5,380 & $10^{0} 05^{1} \mathrm{~N} / 4^{0} 06^{1} \mathrm{E}$ & $\begin{array}{l}\text { E Northern Guinea } \\
\text { Savanna }\end{array}$ \\
\hline ONP & Edo & 181 & $6^{0} 10^{1} \mathrm{~N} / 5^{0} 30^{1} \mathrm{E}$ & Rainforest \\
\hline YNP & Bauchi & 2244 & $9^{0} 50^{1} \mathrm{~N} / 10^{0} 28^{1} \mathrm{E}$ & E Sudan Savanna \\
\hline
\end{tabular}


Table 2: Business structure of and importance of interpretation to Chad Basin, Kainji Lake, Okomu and Yankari National Parks

\begin{tabular}{|c|c|c|c|c|}
\hline Variable & CBNP & KLNP & ONP & YNP \\
\hline \multicolumn{5}{|l|}{$\overline{\text { Business Structure }}$} \\
\hline Pubic Service Model & + & + & + & + \\
\hline $\begin{array}{l}\text { Have legislated responsibility for pro- } \\
\text { viding information/education }\end{array}$ & + & + & + & + \\
\hline $\begin{array}{l}\text { Mission /Vision statement include } \\
\text { reference to interpretation }\end{array}$ & - & - & - & - \\
\hline $\begin{array}{l}\text { Regard Interpretation to be of central } \\
\text { importance }\end{array}$ & + & + & + & + \\
\hline \multicolumn{5}{|l|}{$\begin{array}{l}\text { Interpretation functions considered } \\
\text { to be of central importance }\end{array}$} \\
\hline Increasing visitors' enjoyment & + & + & + & + \\
\hline $\begin{array}{l}\text { Increasing visitors' awareness/ } \\
\text { understanding }\end{array}$ & + & + & + & + \\
\hline As a management tool & + & + & + & + \\
\hline Increasing community support & + & + & + & + \\
\hline To change visitors' behavior & + & + & + & - \\
\hline For commercial reasons & - & + & - & - \\
\hline + Applicable; - Not Applicable & & & & \\
\hline
\end{tabular}

+ Applicable; - Not Applicable

ing of visitors' behaviour, management tool as well as commercial purposes. The result of the business structure of the selected parks is not in conformity with the findings of Department of Natural Resources and Environment (1999) in Australia and New Zealand which showed that only one-third of conservation agencies are now operating within a public service model; although historically they operated under the public service model. Also, legislated responsibility of the parks as regards to interpretation and interpretive services agree with Beckmann (1992) and Cheatley (1989) that information/education functions are enshrined in the enabling legislation of most parks and protected areas in New Zealand, Australia and internationally. Their mission/vision statements with no reference to interpretation are also not in conformity with most parks and protected areas internationally whose many mission statements and corporate plans identify interpretation as a key activity (Canadian Heritage 1994; Royal Botanical Gardens Melbourne 1997; Sutherland 1996).

Table 3: Ranking of interpretation functions according to their levels of importance to the parks

\begin{tabular}{lllll}
\hline Interpretation Functions & CBNP & KLNP & ONP & YNP \\
& Rank & Rank & Rank & Rank \\
\hline Increasing visitors' enjoyment & $3^{\text {rd }}$ & $3^{\text {rd }}$ & $2^{\text {nd }}$ & $4^{\text {th }}$ \\
Increasing visitors' awareness/ & $1^{\text {st }}$ & $2^{\text {nd }}$ & $1^{\text {st }}$ & $1^{\text {st }}$ \\
understanding & & & & \\
As a management tool & $4^{\text {th }}$ & $4^{\text {th }}$ & $3^{\text {rd }}$ & $3^{\text {rd }}$ \\
Increasing community support & $2^{\text {nd }}$ & $1^{\text {st }}$ & $4^{\text {th }}$ & $2^{\text {nd }}$ \\
To change visitors' behaviour & $5^{\text {th }}$ & $5^{\text {th }}$ & $5^{\text {th }}$ & No rank \\
For commercial reasons & 6 th & 6 th & 6 th & No rank \\
$1^{\text {St }}=$ Most important $6^{\text {th }}=$ Least & & & &
\end{tabular}

In the ranking of interpretation functions by the National Parks (Table 3), the study showed that Chad Basin National Park (CBNP) and Kainji Lake National Park (KLNP) ranked interpretation as a means of increasing visitors' enjoyment third $\left(3^{\text {rd }}\right)$ while Okomu National Park (OKNP) and Yankari National Park (YNP) ranked it second $\left(2^{\text {nd }}\right)$ and fourth $\left(4^{\text {th }}\right)$ respectively. Also Chad Basin National Park (CBNP), Okomu National Park (OKNP) and Yankari National Park (YNP) ranked interpretation as a means of increasing visitors' awareness and understanding first $\left(1^{\text {st }}\right)$ while Kainji Lake National Park (KLNP) ranked it second $\left(2^{\text {nd }}\right)$. Interpretation as a management tool was ranked fourth $\left(4^{\text {th }}\right)$ by Chad Basin National Park (CBNP) and Kainji Lake National Park (KLNP) whereas Okomu National Park (OKNP) and Yankari National Park (YNP) ranked it third $\left(3^{\text {rd }}\right)$. Chad Basin National Park (CBNP) and Yankari National Park (YNP) ranked interpretation as a medium of increasing community support second $\left(2^{\text {nd }}\right)$ while Kainji Lake National Park (KLNP) and Okomu National Park (OKNP) ranked it first $\left(1^{\text {st }}\right)$ and fourth $\left(4^{\text {th }}\right)$ respectively. All the parks except Yankari National Park (YNP) ranked interpretation as a means of changing visitors' behaviour fifth $\left(5^{\text {th }}\right)$, Yankari National Park (YNP) did not rank it at all. Also, the selected parks ranked interpretation for commercial reasons sixth $\left(6^{\text {th }}\right)$ except Yankari National Park (YNP) that did not rank it.

The various ranking of interpretive services showed the level of importance each of these National Parks attached to various interpretation functions. In the ranking of interpretation functions by the parks, the function ranked least was interpretation for changing behaviours $\left(5^{\text {th }}\right)$ and for commercial purposes $\left(6^{\text {th }}\right)$; however, Wolfgang (2002) stated behavioural changes as one of the objectives

Table 4: Commitment and understanding of National Parks' staff on interpretation goals and objectives

\begin{tabular}{|c|c|c|c|c|}
\hline Variable & CBNP & KLNP & ONP & YNP \\
\hline \multicolumn{5}{|l|}{$\begin{array}{l}\text { Communication of interpretation } \\
\text { commitment }\end{array}$} \\
\hline Formally through written document & + & + & + & + \\
\hline Word of mouth & + & + & + & + \\
\hline Part of policy manual & - & + & + & - \\
\hline $\begin{array}{l}\text { Understanding of Interpretation } \\
\text { goals and objectives by Park Staff } \\
\text { There is clear understanding among } \\
\text { staff of the parks on interpretation } \\
\text { goals and objectives } \\
\text { Levels of understanding }\end{array}$ & + & + & + & + \\
\hline Senior staff & - & - & + & - \\
\hline Middle staff & - & - & + & - \\
\hline Interpreters/educators & - & - & + & - \\
\hline Site staff & - & - & + & - \\
\hline
\end{tabular}

+ Applicable; - Not Applicable 
Table 5: Interpretive policies and strategies used by the Parks

\begin{tabular}{|c|c|c|c|c|}
\hline \multirow{2}{*}{$\begin{array}{l}\text { Variable } \\
\text { Internal policies/strategies/ } \\
\text { documents used in planning and } \\
\text { managing interpretation services }\end{array}$} & \multicolumn{4}{|c|}{ CBNP KLNP OKNP YNP } \\
\hline & & & & \\
\hline Management policy & + & + & + & + \\
\hline Communication policy/strategy & + & + & + & - \\
\hline Education policy/strategy & - & + & + & + \\
\hline Management Plan & + & + & + & + \\
\hline Action plans & + & + & + & - \\
\hline Guidelines/manual & - & + & + & - \\
\hline $\begin{array}{l}\text { Frequency of reviewing interpreta- } \\
\text { tion policy/strategy /objective by } \\
\text { senior management group }\end{array}$ & & & & \\
\hline At least annually & - & - & - & - \\
\hline Every 2 years & - & - & + & - \\
\hline $\begin{array}{l}\text { Officer from senior management } \\
\text { group responsible } \\
\text { for interpretation policy/standards }\end{array}$ & + & + & + & + \\
\hline
\end{tabular}

+ Applicable; - Not Applicable

of interpretation. Also, interpretation is constantly being used for commercial reasons especially to attract visitors to National Parks.

Table 4 shows the commitment and understanding of interpretation goals and objectives by the staff of the selected National Parks. All the selected parks communicate interpretation commitment formally through written document and word of mouth. Two of them (Kainji Lake National Park and Okomu National Park) communicate it through the policy manual. Also, in all the National Parks, there is clear understanding of interpretation goals and objectives; however there is variation in the staff levels of understanding across the parks. Only Okomu National Park reported clear understanding among senior level staff, middle level staff, interpreters/educators and site staff. Furthermore, the commitment and understanding of interpretation goals and objectives by Nigeria National Parks' staff also agree with the findings by Department of Natural Resources and Environment (1999) that most senior managers $(78 \%)$ have a clear understanding of interpretation benefits, these were clearly understood by site managers (48\%) and planners.

The study further revealed the various internal policies, strategies and documents used in managing interpretive services by the selected parks (Table 5). All the selected parks use management policy and education policy/strategy while three parks (Chad Basin National Park, Kainji Lake National Park and Okomu National Park) use communication policy/strategy and action plans while two of the parks (Kainji Lake National Park and Okomu National Park use guidelines and manuals. However, Kainji Lake National Park, Okomu National Park and Yankari National Park use management plans for their interpretive policies and strategies while Chad Basin National Park did not. Only
Table 6: Environmental interpretive services planning by the parks

\begin{tabular}{|c|c|c|c|}
\hline \multirow{3}{*}{ Variable } & \multicolumn{3}{|c|}{ CBNP KLNP ONP YNP } \\
\hline & & & \\
\hline & - & + & - \\
\hline Identify key audience & + & + & - \\
\hline $\begin{array}{l}\text { Have documented interpretation strategy/ } \\
\text { Plans }\end{array}$ & + & - & - \\
\hline Prepare project/program plans & + & + & + \\
\hline \multicolumn{4}{|l|}{ Use visitor/market research } \\
\hline Not at all & - & - & + \\
\hline Annually & + & + & - \\
\hline \multicolumn{4}{|l|}{ Define for interpretation Services } \\
\hline Goals & + & + & + \\
\hline Objectives & + & + & - \\
\hline Key results & - & + & - \\
\hline Performance indicators & - & + & - \\
\hline Outcomes & - & + & - \\
\hline \multicolumn{4}{|l|}{ Key audience to target } \\
\hline First time visitors & + & + & + \\
\hline Non visitors & - & + & + \\
\hline People who live near the park & + & + & + \\
\hline Experts & + & + & + \\
\hline Schools & + & + & + \\
\hline Tertiary institutions & + & + & + \\
\hline Ethnic groups & - & - & - \\
\hline Overseas visitors & + & + & - \\
\hline Special Interest groups & + & + & - \\
\hline $\begin{array}{l}\text { Identify Key Messages for interpretation } \\
\text { services }\end{array}$ & + & + & + \\
\hline Messages targeted to specific audience & + & + & + \\
\hline
\end{tabular}

+ Applicable; - Not Applicable

Okomu National Park reviews interpretation policy, strategy and objective; this is done by senior managers every 2 years while the remaining three National Parks (Chad Basin National Park, Kainji Lake National Park and Yankari National Park) do not review interpretation policy. Furthermore, all the parks reported that officer from senior management group is responsible for interpretation policy and standards. The selected National Parks adopt various interpretive policies and strategies, the result is in tandem with numerous management agencies in Australia and internationally, which are now producing strategic documents focusing on interpretation and visitor service (Brisbane City Council 1997; Environment Act 1998; McPherson 1995; Turner 1993 and Winkworth et al. 1994).

The study shows that Kainji Lake National Park and Okomu National Park designed and planned interpretation activities to address parks' goals and objectives while Chad Basin National Park and Yankari National Park did not. Also, three of the parks (Chad Basin National Park, Kainji Lake National Park and Okomu National Park) identify key audiences for their interpretive messages or services while one park (Yankari National Park) does not. Only Chad Basin has documented interpretive strategies or plans; Chad Basin National Park and Okomu National Park used visitor and/or market research annually to project their programs when planning interpretative services while Kainji Lake National Park and Yankari Na- 


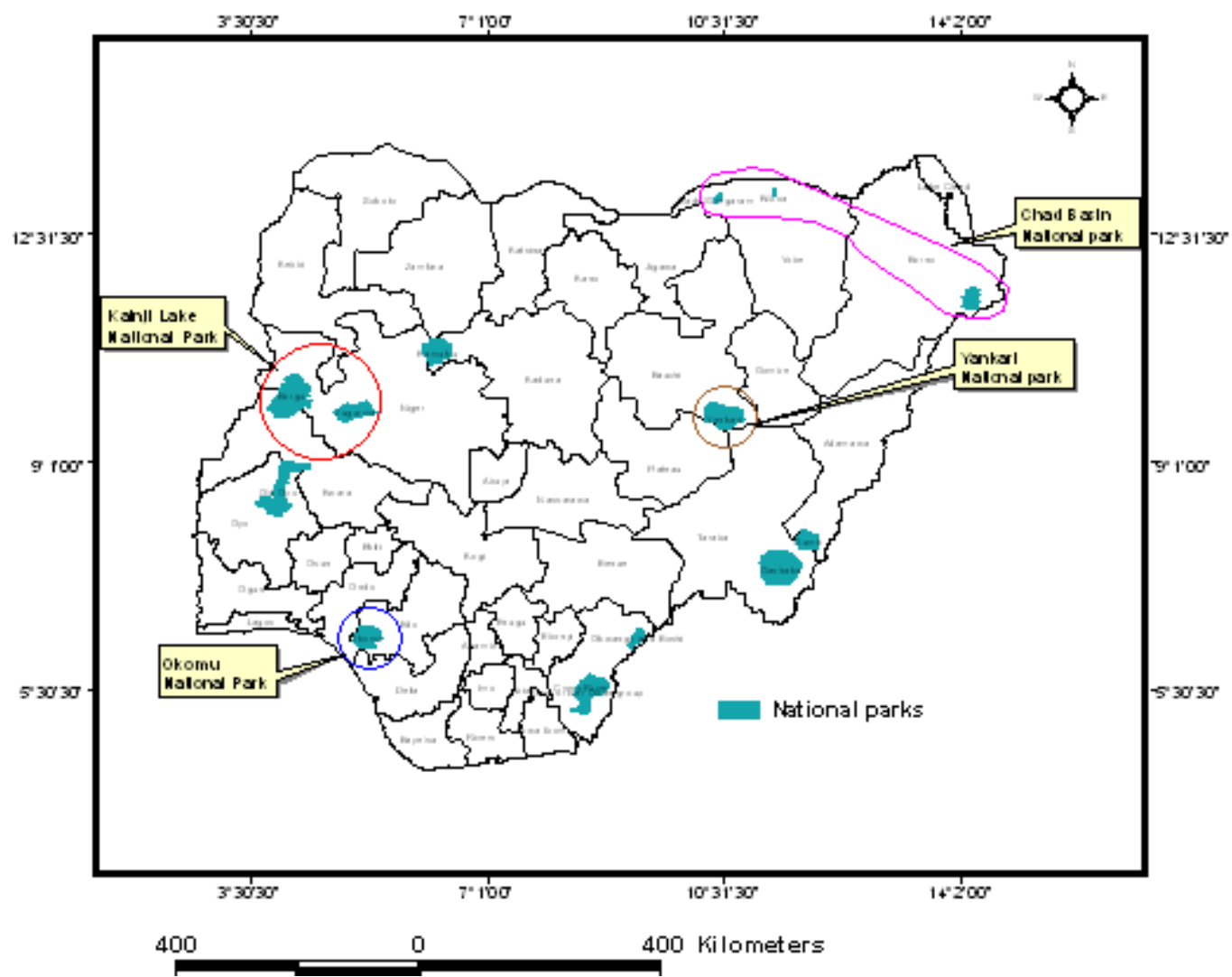

Figure 1: Map of Nigeria showing the selected National Parks for the study and other National Parks

tional Park did not use visitor and/ or market research. All the parks reported to define goals for interpretive services, however, Chad Basin National Park, Kainji Lake National Park and Okomu National Park define objectives for interpretive services, Yankari National Park neither have goals nor objectives for interpretation; while only Okomu National Park defined key results, performance indicators and outcomes for interpretive services. Also, Chad Basin National Park, Kainji Lake National Park and Okomu National Park have put in place a formal process to decide which audience to target. They also identify key audiences for their interpretive messages or services.

All the parks considered visitors from schools as key audience to target; Chad Basin National Park, Kainji Lake National Park and Yankari National Park considered first time visitors as key audience to target respectively. Parks' neighbours (villagers) were considered as key audiences to target by Kainji Lake National Park, Okomu National Park and Yankari National Park while tertiary institutions were considered as key audiences to target by Chad Basin National Park, Kainji Lake National Park, and Yankari National Park while overseas visitors and special interest groups were considered as key audiences to target Chad Basin National Park, Kainji Lake National Park and Yankari National Park. The study further revealed that all the selected Parks reported to identify key messages for interpretive services and their messages were targeted to specific audience (Table 6). These results agree with Australian and New Zealand Environment and Conservation Council Organizations and Agencies which are increasingly using visitors' surveys and other instruments for learning about their audience, identify key messages for their interpretation and target key messages to specific audiences (Department of Natural Resources and Environment 1999; Cheatley 1994 and Stetski 1994a).

\section{CONCLUSIONS}

The Nigeria National Park System considered to a varying degrees environmental interpretation/ interpretive services as core activities based on various functions and benefits derivable from interpretive activities and services in the management of the various parks. Also, to a certain level, interpretive services are planned to meet the parks' goals and objectives, however, only one of them defines key results, performance indicators and outcomes for interpretive services. These are missing links in evolving an adequate and appropriate planning for interpretive services and the fulfillment of interpretive goals and objectives. Greater emphasis is needed in developing appropriate interpretive plans 
particularly documented interpretive plans/ strategies and programs that can shape visitors' and park neighbours attitude towards National Parks' policies and activities as well as using interpretive services to project the tourism potentials of Nigeria to the outside world in order to optimize the gains from global tourism market and to enhance the achievement of Millennium Development Goals (MDGs) of eradicating extreme poverty (through increased economic benefits to local communities from ecotourism ) and ensuring environmental sustainability in the country.

\section{REFERENCES}

Abramovitz JN1991 Investing in Biological Diversity. In U.S. Research and Conservation Efforts in Developing countries. World Resources Institute, Washington, D. C.

Beckmann EA1992 Environmental Interpretation for Education and Management in Australian National Parks and other protected Areas. Unpublished Doctoral Thesis.

Brisbane City Council 1997 National Areas Communication Strategy. Unpublished document.

Canadian Heritage 1994 Guiding Principles and Operational Policies, Minister of Supply and Services: Canada

Cheatley B 1989 Interpretation and Environmental Education for Marine Protected Areas: A Review of Current Approaches and a Strategy for the Bunurong Marine Park, Victoria, Masters Thesis at Monash University.

Cheatley B 1994 Managing the Visitor Experience: Knowing your Current and Potential visitors is the First Step' in (Eds) E Beckman and S Hull Interpretation Attached to Heritage, Papers presented at the Third Annual Conference of the Interpretation Australia Association 1994, Interpretation Australia Association: Australia.

Department of Natural Resources and Environment 1999 Best Practice in Park Interpretation and Education. A Report to the Australian and New Zealand Environment and Conservation Council Working Group on National Park and Protected Area Management Benchmarking and Best Practice Program Prepared by Earthlines Consortium, Victoria.

Environment Act 1998 Tidbinbilla Nature Reserve Interpretation Strategy, Unpublished document.

McPherson K 1995 Rationalizing Visitor Services Programs in Ontario Parks, Interpscan,_vol. 22, no. 3, Pp. $2-3,14$

Nisbet EG 1991 Leaving Eden to Protect and Manage the Earth, New York: Cambridge University Press.
NPS 1998 Resource Interpretation Natural Resource Year in Review (1998) National Park Service 1998

Onadeko SA and Meduna AJ 1984 Public Relations and Wildlife Management in Nigeria. In Okoro OO and Fuwape JA (eds.) Proceedings of the $19^{\text {th }}$ Annual Conference of the Forestry Association of Nigeria, Port Harcourt, December 3 - 8, 1984. Pp. 195 - 197.

Peters SW 1995 Introduction to Environmental Education Nigeria Conservation Foundation, Pp. $1-6$

Reid WV and Miller KR 1989 Keeping Options Alive: the scientific basis for conserving biodiversity. World Resources Institute, New York.

Royal Botanic Gardens Melbourne 1997 Corporate Plan 1997-2002 Royal Botanic Gardens: Melbourne.

Stetski W 1994a Future Trends in Interpretation, Interpscan, vol. 21, no.1 Pp29.

Sutherland L 1996 Interpretation and Visitor Services-An Evaluation of Policies and practices in Australia's Botanic Gardens, Unpublished Master thesis.

Tilden F 1977 Interpreting Our Heritage (third edition) Chapel Hill, University of North Carolina Press.

Turner M 1993 The Big Wet Picture: A Public Education Strategy for the Great Barrier Reef World Heritage Area in (Eds) S Olsson and R Saunders Open to Interpretation 1992 Conference papers of the Inaugural conference of the interpretation Australia Association, Interpretation Australia Association: Australia.

Westing AH, Warwick F and Renner M 2001 Environmental Degradation as both Consequence and Cause of Armed Conflict: Working Paper Prepared for Nobel Laureate Forum Participants by PRECOM Sub-committee on environmental deregulation, PRECOM.

Whitmore TC and JA Sayer 1992 Tropical Deforestation and Species Extinction. IUCN Forest Conservation Programme, Chapman and Hall, London. Pp 49

Wilson EO (eds) 1988 Biodiversity. National Academy Press, Washington DC.

Winkworth K, James P and Freeman, P 1994 Interpretive Strategy for Tasmania's Parks Reserves and Historic Sites, Unpublished document.

Wolfgang AWS 2002 Methodical Approach: Environmental Interpretation. FH Stralsund-Leisure and Tourism Management. http://www.touris mus-museum.de 